\title{
IV. 21世紀の発達心理学を展望する
}

$\begin{array}{llll}\text { 企画・司会 } & \text { 依 } \text { 田 } & \text { 明 (横浜国立大学) } \\ \text { 話題提供者 } & \text { 鹿 取 広 } & \text { 人 (東京大学) } \\ & \text { 永 野 重 } & \text { 史 (国立教育研究所) } \\ & \text { 空 井 } \text { 健 三 (中京大学) } \\ & \text { 安 香 } & \text { 宏 (千葉大学) } \\ \text { 指定討論者 東 } & & \text { 洋 (東京大学) } \\ & \text { 麦 島 文 夫 (科学警察研究所) }\end{array}$

\section{企画者として}

\section{依田明}

わが身の浅学非才をかえりみず，何ゆえにこんな大そ れたテーマのシンポジウムを企画したのか。発表論文集 に書いたことが, 基本にある。つまり, 最近の教育心理 学の研究は「きれいな研究」ばかりで, 人間らしさ, な まなましさが失われているという欲求不満である。

そのうえに 3 つの理由が加わった。第 1 は, 総合準備 委員長である永野重史に対する協力である。大会準備委 員長をつとめるのは, 定年まじかの老教授といら慣行で あった。今回は，50を超えたばかりの永野がつとめるこ とになった。古くからの友だちとしては, 彼のために一 肌ぬごうと考えたのである。

第 2 は，祭の花火にしょうと思ったことである。筆者 は, 総会は一種の祭とみなしている。祭には, 華々しさ も必要である。

第 3 は, 最近のシンポジウムに対する不満である。話 題提供者は, 総会の口頭発表のように細かなデータをぼ ろぼろしゃべる。盛り上りにかけること，はなはだしい。 シンポジウムをひとつのショウといったら，いいすぎで あろら。けれども, 参加者全員が高揚した気分になれる， （はやりのことばを使えば）パフォーマンスであっても よいではないか。

このような趣旨で, このシンポジウムを企画し, 司会 をした。幸, 大ぜいの会員が参加してくださった。成功 したかどうかは，参加者の判断にまかせたい。

以下に, 話題提供者と指定討論者の発言の要旨をのせ る。これらの文章は, とくにこの年報のために書いても らったものである。発表論文集のサマリイといっしょに お読みいただきたいと思ら。

\section{1世紀の発達心理学を展望する}

\section{鹿取 広人}

一知覚・認知発達研究の立場から—

1）知覚・認知発達の研究分野では, 1960〜70年代よ
り, 新生児・乳児など, 初期状況の発達研究が活発とな り, 知覚機能の行動的研究の一部は, 乳児精神物 理 学 Infant psychophysics の名でよばれて, 多くのアカデ ミックな研究者の注目を集めている。これらの研究によ って, 行動的データと神経生理学的データとの関連ゔけ のきっかけが与えられ, 境界領域間の相互の情報交流が 生じつつある。それらは, 動物を被験個体とした実験研 究を取り込んで, 心理生物学 psychobiology ないし生 物心理学 biopsychology として今後益々発展していく と思われる。

但し, それらの研究は従来, (1) 視覚の研究が主であ り,ごく最近に聴覚の研究が行われてきたにすぎず, 他 の感覚モダリティ, とくに知覚・認知発達にとって重要 な役割を果たすと思われる触運動知覚の研究がほとんど 欠けており, 当該研究の将来の発展が望まれる。

2）以上の研究のよって立つ哲学は, 還元主義的楽天 主義が暗々裹に含まれている。還元主義自体は, 科学的 思考法としてきわめて生産的で, 心理学はそれによって 大きな進歩を遂げてきたことは事実であるが，iうの有 効な手段にすぎず，システム全体の特性や機能を見逃が してしまう危除性をはらんでいる。統一的個体としての 子どもの発達過程の仕組みを明らかにしようとする発達 研究にとって,このことはきわめて重大である。

したがって個々の成分のメカニズムの分析と同時に, 全体のシステムとしての心性の再統合の作業が必要であ る。この作業をどうやって行らかは, 個々の研究者の選 択にゆだねられている。

3）その 1 つの可能性として, 知覚・認知の発達と初 期のコミュニケーションないし言語行動とのからみ合い を明らかにすることが，そのための 1 つのきっかけを与 えることになるだろう。母子関倸の中での初期の知覚・ 認知の働きの分析から, 知覚・認知の発達と, 情緒, 動 機づけ, 社会性の発達とのかかわりが解き明かされてい くことになるかむ知れない。

4) 他の発達研究と同じく, 知覚・認知発達の研究分 野でも，遺伝対環境問題が，絶えずむし返されてくると 思われる。その場合, 先の心理生物学的データとともに 社会生物学の資料から貴重な示唆を与えてくれることに なるかも知れない。いずれにせよ，そうした問題には進 化論的な視点が，なんらかの示唆を与えてくれるだろう。

この問題と関連して, 西欧的規準, 価値観を暗々裏に 前提とした知覚ないし認知発達の段階仮説に対して，1 つの反省が生まれてくると思われる。いわゆる形式的論 
理を認識の最高レベルとして措定してよいか否かが十分 検討されなければならない。

5）他の分野の研究と同じく, わが国の研究の多くは, 欧米の後追いの研究であった。それを脱っするには，わ れわれの現実の状況から出発した問題設定が必要である。 眼の前に置かれた固有の問題から出発し，それを学問的 に純化させることによって, 従来ともすれば, 別個に分 離されていた実験室的基礎研究と, 実践的, 臨床的研究 との相互の関係づけが拓かれると思われる。そこでは, 自由な天才的洞察と並んで, 現実に与えられた状況でそ れなりの仕事を着実に果たす粘り強さが要求されるだろ う。

\section{教育研究の立場から}

\section{永野 重史}

教育界には, 互に矛盾する, 心理学上の「定説」が罷り 通っている。ひとつは, 行動主義的な学習理論で,「子 どもをしつけるには, ほめ方と叱り方をじょらずにすれ ばよい」といらもので, もらひとつは, 「学習指導は, 発達段階に応じておこなわれるべきものである」という 主張である。第 1 の考え方によれば, 子供の発達の目標

（行く先）は，あらかじめ決まっているものではなく， 周囲の人間がどら考え，賞罰をどのように与えるかで発 達の方向が決められるといらことになるが，第 2 の考え 方では, 進化論における定向進化説と同様, 発達の目標 はあらかじめ決まっており, 子供の心の発達は, 年齢の 増大とともに自然に進行するものと考えられている。ヴ ィゴツキーの表現を借りれば, 教育はそのような発達を あとから追らようにしておこなわれることになる。この

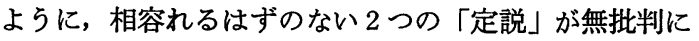
是認されている今日の状況は, 速やかに改められなけれ ばならない。

その為には, 理論に関して潔癖であろらとするだけで なく, 教育問題に発達心理学の知識を生かす際に, もっ と良心的でなければなるまい。

科学としての心理学を樹立することをいそぎ過ぎると， かえって問題そのものを見失うことになる。筆者の学生 時代は行動主義全盛時代で, 心を失った心理学の時代で あり，「思考」ということばを用いることも許されなか った。それでいて, 知能検査が子供の一般的な知的水準 を測るといらことについては，疑いがもたれていなかっ た。筆者は, その時代に，5歳児にひし形をかかせるに はどらしたらよいかとか，子供と押上げポンプをいじり ながら，子供が持っている「エネルギー概念」の芽ばえ を探ったりしていたのであるが，その際に，現在注目を 集めている「発達近接領域」の問題や，日常生活の中で
の「認識」の問題を考えていたのだと思う。

現在, 学習の個別化という主張がにぎやかであるが, ブロンフェンブレンナーの生態論的発達心理学や, 最近 問題となっている「文脈主義的視点」から考えると，人 間はひとりだけで成長することはないはずなのに，これ までの心理学は, 学習についても, 発達についても個人 を重視し過ぎて，個人を含む状況を軽視していたように 思う。

そもそも，時代と地域をこえた普遍的な人間の性質を 明らかにすることによって，心理学が学問として独立し ようとするところに無理があるのであって，たとえ心理 学が学問として独立することがなくなってもよいから， 社会的歴史的状況の中で育つ人間の姿を理解しょうとす ることが，今後の発達心理学の課題であるよらに思う。

\section{非社会的行動研究の立場から}

\section{空井 健三}

臨床心理学を専門領域とする者が日常の臨床実践から 得た人間の発達の現代的変化を考察することによって将 来の発達心理学を展望する一助としたい。

1, まず，心理検查による発達の変化を，人物画なら びに幼児・児童絵画統覚検查の結果をスライドによって 示す。描画は一般に三才後半から可能となり, 一定の特 徵を示しながら生活年齢の上昇とともに人物画は進歩・ 完成していく。ところが，小学校 5 年にはじまり中学・ 高校生を特徴づける人物画の変化がある。その特徴とそ れが意味するものを例示すれば，「目・鼻・口の欠如」 は引込多思案や性の概念の不明さを，「腕を後にかくす」 のは仲間と協調できないことを，「手のあいまいさ」は 対人関係からの逃避を，「腕と胴の密着」は受動的・防 衛的態度を,「脚の密着」は緊張感や性的不適応を, そ れぞれ意味し，示唆している。上記の「密着」はマンガ の影響によるのではないかとの疑いがもたれたが，これ は実際のマンガを検討することにより否定され，上記は いずれも現代のとくに中・高生の特徴であることが判明 した。さらに幼児・児童絵画統覚検查に招いて，挫折を 示唆する像が主人公として選択される率が小学校 1 年か ら一次曲線的に増加していく傾向が指摘された。

2. 上記の上うな不健康といえる現代的特徴が発生し た由来は，その特徵をもつ中・高校生のみを対象に検討 したとしても解明し得ず, 臨床的経験からみると，ひろ く文明の変化が幼児からの生活に与えた影響に目をむけ ることが必要となる。

人工ミルクが開発され，母乳に代る率が高くなるにつ れて, 文明人の母親倣哺乳類の母親としての感覚を失っ ていった。この結果が産院における子どもの取りちがえ 
である。さらに，自分の子であるといら感覚があいまい になってしまった証左としてコインロッカー事件の発生 がある。そして, 最近の紙掞むつの普及は, 嵄けのもと となる不快感を幼児から奪い，おむつをかえるといら母 親の幼児への重要な接触の回数を減らしてしまい，母親 は幼児に無関心に夜高斯で寝かせる結果を招来した。ま た，第一次反抗期は，いずれ個人として生きねばならな い文明人にとってはじめの個への目ざめであり, 反抗に よって自分をたしかめるが，永い間反抗の素材であった 物の欠乏が消失してしまったために子どもたちは反抗の 機会を失った。この反抗体験がないために青春期におけ る第二次反抗期の反抗は歯どめを知らず，その結果が家 庭内暴力であり, 限度を知らぬ現代のいじめにつながっ ている。さらに文明の進歩は, 我々の生活を楽にした代 り, 苦労して求めずとも得られるいわば動物園の動物の 生活へ我々を追いこんだ。しかも外敵に関心を払わなく てよいために他者への関心も失なわれていった。このよ らにして，なるべく気くばりは失われていったのであ る。この無関心さが人物画テストに示されているのであ る。しかし, 人間は, 基本的な安全感や他者への信頼感 なしに安定した精神生活を送ることができない。前述の 事情はこの安全感や信頼を疑わしいものにしてしまった。 そこに, 挫折感が成長するごとに強まる原因がひそんで いるが，これは絵画統覚検查結果に示されているが，現 代において精神分裂病とも神経症ともつか境界例とい 5厄介な問題者が多発していることもこれと関係が深い。 境界例は, 精神医学の薬物治療において著効なく, 心理 療法においても境界例患者が，綝返し飽くことなく治療 者を信頼できるかどらか疑い試し，しかもそれを意識的 には気づいていないという事情がそれを物語っている。

我々心理臨床の実践家にあっては, 個人の発達史をぬ きに対象に接することは不可能に近いし, Werner, Freud, Piaget などの発達理論は重要な基礎の一部を提供 してきているが上記の事情からすれば, これらの発達理 論も部分的な修正を必要とすると考えられるし，また我 我からみて，文明の変化にあまり眼をむけることの少な い発達心理学ならば, 将来む期待はし得ない。オイル・ ショックを分岐点に, 過度の文明の発達が害を我々に及 ぼすことになった現在, 発達心理学も広い視野から見な お寸時期にきているのではないだろらか。我々の立場か らすれば, この成否が21世紀の発達心理学を決めると思 われる。

\section{反社会的行動研究の立場から}

安香 宏 1920年代から30年代にかけて確立された反社会的行動
（とりわけ犯罪や非行）についての考え方，たとえば $\mathrm{W} ・$ ヒーリーの情動障害説や欲求不満説, あるいは, 支 配的文化からはみ出した非行的下位文化を考える $\mathrm{A} \cdot \mathrm{K}$ ・ コーヘンらの説などを, 根底からくつがえすような様相 が現われてきたのは, アメリカでは1960年代のはじめ, 日本では1970年代のはじめである。一言でいってしまえ ば, 通常態の中からの非行, つまり, 知的な障害や人格 の偏り, あるいは，緊張をはらんだ崩壊・貧困家庭や下 層・低文化階級といった条件を全くそなえていない， “ふつらの家庭のふつうの子供”によって, 日常行動の 延長上で少しの罪悪感も伴わずになされる非行の出現で ある。それはまた, 能動性の希薄, 狭い生活空間の中で の逸脱，方向性を持った反発や敵対の減少，焦点の定ま らない暴発といった意味での, 非社会的色彩を色濃く持 つもので, これは, 今後ますます増えていくであろう。

具体的に列挙してみると, (1)社会的弱者 (老人, 浮浪 者, 家族など) への加害, (2)自己破壊を伴う違法行為 (原始反応, 薬物への耽彁, 自傷行為でもある他者への 暴行など), (3)無力感を伴う宿命観を過度に補償する 形 の暴発（露出症的顕示, スター襲撃, 生きがいを求めて の不特定多数の他者の殺傷など）が, 今後は増加してい くであろう。

これに対して, 社会の側の対応には, (1)他力本願的秩 序維持, (2)保護主義でなく厳罚主義, 行為者主義でなく 行為主義, (3大人と子供との間での相似の傾向, たとえ ば, 価值観の単純化や便宣主義などが, 顕著になってい くであろう。

このような反社会的行動の, 今後に予想される動向に 対して, 発達心理学が検討を迫られることになるであろ う課題を列挙するならば，次のようになる。

(1)価值とその伝達, 社会変動の急速化と時間的展望の 閉塞, 世代の消滅といった問題

生きていくために必要でないものは価值ではないとい った割り切った見直しが必要ではあるまいか。老人があ まり長生きすることがほんとうに社会のために良いこと なのかどうか。電車の中で若者が老人に席を譲らないの は, ある意味では合理的なことなのかもしれない。ホン ネと全くかけはなれたタテマエだけの価值や規範をいく ら押しつけていても，そしてそれを受け入れないからと いって「今の若者は…」と嘆いていても，はじまらない。 価值には永続性がなくなってきている。社会変動のピ ッチが早まれば当然であろう。したがって，価值の伝承 ということがなくなっていき，世代というものも消滅し ていくであろう。残るのは年代だけであり，大人も子供 も同じテレビを観たり同じマンガを読むのはあたりまえ となる。そこをはっきり認めないで，100 年前と同じ調 
子で親子関係だのしつけだのと説いていても，はじまら ない。

\section{(2)「社会」とは何かの問題}

社会性とか社会的責任などというときの,「社会」を どのようなものと考えるかを，今をでのようになおざり にしておくわけにはいかない。大学の教師が社会人だな どとは，大学の教師以外の人はだれでも考えてはいない のではあるまいか。前述の「生きるため」ということと 考え合わせて，もっと個別的あるいは身辺的に考える必 要があろう。そうすれば, 協調性, 行動の統合性や持続 性, 自己満足（自己実現ではない）といった，没価值的 な人格特性に還元できる部分を，かなり発見できると思 われる。

(2)反社会的行動の持つポジティブな意味

反社会的行動であっても，その者にとっては生きるた めの 1 つの試みであることを，忘れるべきではない。た とえば，不良交友と非難するが，それなら良好交友がふ つうの子供の世界にあるのかどうか，考える必要がある。

(3)「心理学不要」と言われかねない反社会的行動の世 界

㐫と決めつけるのは, 心理学ではなく，それこそ「社 会」の側である。究極のところ, 反社会的行動は処断さ れる。それまでの過程において，心理学にお呼びがかか っているというだけで, 処断に際しては心理学は全く必 要がない（死刑執行に際して心理学が関与する面がある かどらか考えてみればわかる)。そして，それまでの過 程でも，モタモタしていればすぐにお払い箱になるので ある。心理学にとっては，良い試練の場と考えられない であろうか。

\section{コメント 1}

\section{東 洋}

興味深くうかがったが, どうしても21世紀後半の回顧 の方が多くなって,「これからこうやって発達心理 学を 拓いていく」という方向が十分に出ていないように思う。 発達心理学ばかりでなく心理学一般に, もっと前向きの 活力が欠けているのではないか。中国で文革中に心理学 を「偽科学」として弾圧したという。それは残念なこと だったが，その記憶を持つ中国の心理学者は偽科学でな いことを実証するために，理論的なきびしさをつくる上 でも実践面とのかかわりの上でも，いろいろな努力をし ている。わが国は見かけ上心理学が隆盛であるが，その 隆盛を支える内的活力が盛り上って来ないと空洞化が生 ビたりぜい肉がついたりする。今ここで，われわれが， われわれの研究の対象と, 理論と, 方法とについてきび しい自己点検をし, 発達心理学という研究分野, その研
究者の集団が, どういう意味でその存在を正当化できる のか考えて見る必要があるのではないだろらか。保証さ れた職域で, 強い理論む, 強い実践的かかわりも無しに, 伝統的テーマや流行テーマにヴァリエーションをつけな がらいじっているだけといらのでは, 天下の粟を喰むこ とを正当化できない。

そういう意味で21世紀の発達心理学者として, 次のよ うな型のすぐれた研究者が出て来ることをのぞみたい。 (1)エンブリオ的純粋科学の方向

（例：永野のひし形・ポンプ）

・発達について科学的好奇心からまとめてみるのも必 要である。

・疑問があるからそれに取り組む研究，むう少しわか りたいといら形での研究。

・自分の手をくだした手作りの観察や研究が非常に大 事である。

(2)パラバイオロジカル科学の方向

(例：鹿取の一部の研究）

・生理学的データの関連づけを行う。

・生理学を基礎の科学として行動を研究する。

-「学」としての独自性より「研究者」としての独自 性を確立する必要

(3)実践的アプローチ（例：スキナリアン, 細谷純）

-人の精神発達の研究を通じての心理学的訓練を素堒 として，具体的にどうしたらよいかという方法を経験 的な証明を経て構筑する。

(4) social science から policy science へ向からような 研究（例：中国の心理学者のひとりっ子政策の把え 方の大きさと本気さ)

\section{コメント 2}

\section{麦島 文夫}

私の役割は，基本的には，未来に向かって頑張ろうと している方達に, その努力に敬意を表し, 出来るなら元 気が付くように励ますことと承知して居ります, 言うま でもありませんが，21世紀の心理学がどうなるかは，こ の発表者を含めてここにお集まりの人達の努力によると ころが大きいでしょうから，ここで元気になれれば，そ れが未来の発達心理学のあり様を大きく決定することで しょう。以上を前置きとします。

ある学問分野の未来を決定するものは, (1)その分野の 過去の歴史として作られた母胎から自然的に発する方向 づけ, あるいは学問の内なる知的好奇心から生じる興味 の方向, 強さ (2) そ分野に独特な研究法の開発の如何 (3)この分野に寄せる社会からの要請と援助 (4)この分野 の研究者の社会的地位, 役割の如何, などによって決ま 
ると思えます。これらの項目に従い，発表者の発言を見 た。 て行きます。

発表者はそれぞれ各自の過去を真剣に振り返っていま した。前に進むために後ろを見る必要がある以上この 努力は当然のことでしょうが，その過去を更に大きく振 り返る時, この心理学の過去に指導的な役割をしたシン ボル, あるいはより大きくは, 人間の発達についてのイ メージが何であったかを見る必要があるでしょう。そら 見る時, これまでの発達心理学では, 白紙説, 性善説, 進化論等々が大きく働いていたと思います。それらがこ れからの未来にも，な指指導的なイメージとなるかどう か, 論者の発言には, これらの枠に入り切らない見方が あるのを感じすす，1人は個に根ざした自発（永野）的 活動を重視していましたそれは性善説の方向ではありま すが白紙説ではありません。私の属す犯罪学の分野では 最近は性善説よりも性悪説を基本的イメージとする理論 が重視されるように感じます。この見方を発達について 検討して欲しいし，そのようなイメージとして特に白紙 説よりは素質的なものをも一度見直す必要を感じます。 論者の 1 人が生理的基盤を話題としました（鹿取）が, それを更に広げるなら，素質についての新しい見方につ ながると感じました。

また, 人の精神活動についての知・情・意といら見方 に従らと今世紀は, 知に始まり情が次いで問題となり人 間の知と情の発達が研究の中心でしたが意の面は最近ま であまり研究されなかった。それに対し最近の非行は自 律体が中心的 (安香) 問題との指摘がありました。非行 に限らずこれからの発達研究では, 意的な面が重視され ねばと思います。

(2)の要因とした研究法の開発については余り話題とな らないよらでしたが, それでも reauctionism の批判や， 幼児の指導に当たって, その個から発せられる知的関心 との関連で周囲の大人の対応を分析しその発達への効果 的援助を考えよとの貴重な意見を聞くことが出来まし
(3)としてこの分野に寄せる社会からの要請援助を考え ます。これまで世間の人は困った時は心理学者にきくと 言らことで随分沢山の相談があったと思います。しかし それに対し果たして我々が十分に応えてきたかは非常に 疑問です。

この要請・相談には, 大きく弱者からの相談と強者か らのポリシィー・サイエンスとしての要請があります。 この後者からは要請も, 同時に援助も最近は必ずしも多 くはないと感じます。それは決して好ましい方向ではな い。我々の援助が基本的には弱者に向けてのものである のは確かですが，そのためにも，強者を無視することな く,その要請に適格に応えたい。

その場合, どのような要請に応え, どの方向に援助す るかについて, これからの発達心理学は自分自身の答え を持たねばならない。それは一口に言って，人生の豊か さとは何か，あるいは好ましい人の在り様についての答 えです。それを心理学の中から発見して行く必要がある でしょう。

なお(4)とした, 心理学者の地位・役割については省略 しました。しかしそれについても十分にこれから考えて 行きたい。

最後に発達心理学の未来を考える時, その基本的イメ ージとして次を提案します（これは，この討議参加者に 宿題としたのですが残念ながら答えがなかった）すなわ ち,これまでの発達心理学は個人に即した発達といら視 点に偏っているが，本来発達とは「その集団の中でのみ 可能であり, その集団参加者全員の発達の中で各個人の 発達もある」との視点です。そのことは先に述べた人生 の豊かさへの答とも連なり, あるいは男女のあり方, 家 庭のあり方と発達との関係を考える時の基本的視点にも なると思えます。その視点から発達心理学が新しい未来 を拓く可能性を期待します。 